\title{
Co-infection of broilers with Ornithobacterium rhinotracheale and H9N2 avian influenza virus
}

\author{
Qing Pan', Aijing Liu', Faming Zhang ${ }^{2}$, Yong Ling ${ }^{1}$, Changbo Ou' ${ }^{1}$ Na Hou ${ }^{1}$ and Cheng $\mathrm{He}^{1,3^{*}}$
}

\begin{abstract}
Background: Since 2008, a progressive pneumonia has become prevalent in broilers and laying hens. This disease occurrs the first day after hatching and lasts more than 30 days, resulting in approximately $70 \%$ morbidity and 30\% mortality in broilers. The objective of this study was to isolate and identify the pathogens that are responsible for the progressive pneumonia and establish an animal model for drug screening.

Results: 193 serum samples were collected from 8 intensive farms from 5 provinces in China and analysed in the current research. Our clinical survey showed that $65.2 \%$ to $100 \%$ of breeding broilers, breeding layers, broilers and laying hens were seropositive for ORT antibodies. From 8 intensive farms, six ORT isolates were identified by PCR and biochemical assays, and two H9N2 viruses were isolated. Newcastle Disease Virus (NDV) and Infectious BronchitisVirus (IBV) were excluded. Typical pneumonia and airsacculitis were observed both in broilers inoculated intraperitoneally with an ORT isolate alone and in those co-infected with ORT and H9N2 virus isolates. Specifically, the survival rate was 30\%, 20\%, 70\%, 50\% and 90\% in birds inoculated with ORT+H9N2 virus, ORT followed by H9N2 virus, H9N2 virus followed by ORT, and ORT or H9N2 virus alone, respectively.

Conclusions: The results of this study suggest that ORT infections of domestic poultry have been occurring frequently in China. ORT infection can induce higher economic losses and mortality if H9N2 AIV is also present. Although the isolation of ORT and H9N2 virus has been reported previously, there have been no reported co-infections of poultry with these two pathogens. This is the first report of co-infection of broilers with ORT and H9N2 virus, and this co-infection is probably associated with the outbreak of broiler airsacculitis in China, which has caused extensive economic losses.
\end{abstract}

Keywords: Isolation, Characterisation, Ornithobacterium rhinotracheale, H9N2, Co-infect, Broiler

\section{Background}

Ornithobacterium rhinotracheale(ORT) causes respiratory infections, such as airsacculitis and pneumonia, in birds all over the world. ORT can be a primary or secondary etiological agent, depending on the strain virulence, environmental factors, the immune status of the host, and the presence of other infectious agents [1]. In recent years, outbreaks of respiratory disease associated with ORT have been reported all over the world, including the USA, France, Netherlands, Belgium, Spain, Germany, Hungary, Israel, Korea, Japan, Taiwan, Turkey,

\footnotetext{
* Correspondence: hecheng@cau.edu.cn

${ }^{1}$ Key Lab of Animal Epidemiology and Zoonosis, Ministry of Agriculture, College of Veterinary Medicine, China Agricultural University, Beijing 100193, China

${ }^{3}$ College of Veterinary Medicine, China Agricultural University, Yuanmingyuan Xilu, Haidian District, Beijing 100193, P.R. China

Full list of author information is available at the end of the article
}

Brazil, Iran and South Africa [1-9]. This pathogen can cause economic losses in the poultry industry due to growth retardation and the designation of infected carcasses as unacceptable for human consumption $[1,6,8]$. The H9N2 avian influenza virus (AIV) is not only widespread in poultry, but it also has important implications for human health as a zoonotic infection $[10,11]$. Previous studies demonstrate that H9N2 virus infection contributes to respiratory distress and is involved in diseases caused by other respiratory pathogens in the poultry industry [12,13]. More recent reports indicate that two virulent Chinese isolates of H9N2 virus induced acute respiratory distress in mice [14], which are widely used in biomedical research, suggesting a potential public health risk.

Since 2008, progressive pneumonia has become prevalent in broilers and laying hens. This disease occurs on

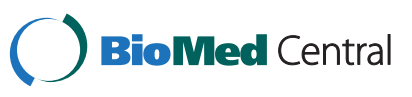


the first day after hatching and lasts for more than 30 days, resulting in approximately $70 \%$ morbidity and $30 \%$ mortality in broilers. In total, we isolated six ORT strains and ten H9N2 AIV strains from the field samples. Five of the six ORT strains were presented simultaneously with H9N2 and the other ORT was isolated from the breeder's eggs. Although ORT and H9N2 have been isolated and identified separately in previous reports, there have been no reported co-infections of poultry with these two pathogens. In the current report, we present the characterisation of ORT and H9N2 isolates obtained from co-infected broilers, with the objective of understanding the aetiology of severe avian pneumonia.

\section{Methods}

\section{Chickens and sampling procedures}

In this study, a total of 291,000 chickens from 8 intensive farms in 5 provinces of China were evaluated, including 70,000 affected breeding broilers, 100,000 affected breeding layers, 95,000 broilers with pneumonia and 16,000 affected layers. In addition, 10,000 unaffected broilers were used as controls. In total, 193 serum samples were collected for the detection of antibodies against ORT using a commercial testing kit. The samples originated from Liaoning, Inner Mongolia, Hebei, Shandong and Beijing represented the ORT prevalence in Northern China.

\section{Antibody detection}

Serum samples were tested for the presence of ORT antibodies using the FLOCKCHEK* Ornithobacterium rhinotracheale Antibody Test Kit (IDEXX GmbH, Switzerland) in accordance with the manufacturer's instructions. All of the measurements were performed in duplicate, and the matching serum pairs were analysed on the same microtitre plate. The results were normalised using the positive and negative control sera provided in the kits and were expressed as the $\mathrm{S} / \mathrm{P}$ value according to the following formula: $\mathrm{S} / \mathrm{P}=(\mathrm{OD}$ sample OD negative control)/(OD positive control - OD negative control). Sera with S/P values less than or equal to 0.4 were considered negative, and sera with $\mathrm{S} / \mathrm{P}$ values greater than 0.4 were considered positive.

\section{Isolation and characterisation of ORT}

The current study was approved by the Animal Care and Use Committee at China Agricultural University and was carried out in accredited animal biosafety level 3 facilities. The trachea and lungs were aseptically obtained from ORT serum-positive broilers. Streak cultures were performed using standard I nutrient agar (Merck, Germany) with 5\% sheep blood and were incubated at $37^{\circ} \mathrm{C}$ under aerophilic conditions for $24-48 \mathrm{~h}$. The positive colonies were identified by Gram stain and biochemical assays [1]. The biochemical tests assayed for oxidase, catalase, lysine, urea, indole, sulphuric acid $\left(\mathrm{H}_{2} \mathrm{~S}\right)$, nitrate, gelatinase, motility, and carbohydrate fermentations, including glucose, mannose, lactose, sucrose, maltose, and galactose $[2,7]$.

DNA samples were extracted from the positive ORT isolates using the DNeasy Tissue Kit (Qiagen, Germany) following the manufacturer's instructions. The primers used in the study were designed based on the available gene sequence [1]. The forward primer was 5'- GAG AAT TAA TTT ACG GAT TAA G-3', and the reverse primer was 5'-TTC GCT TGG TCT CCG AAG AT-3'. A 784-bp fragment of the $16 \mathrm{~S}$ rRNA was amplified and subjected to electrophoresis in a $1 \%(w / v)$ agarose gel. The PCR procedure included an initial incubation for $5 \mathrm{~min}$ at $94^{\circ} \mathrm{C}, 45$ cycles for $30 \mathrm{~s}$ each at $94^{\circ} \mathrm{C}$, annealing at $52^{\circ} \mathrm{C}$ for $60 \mathrm{~s}$, and extension at $72^{\circ} \mathrm{C}$ for $90 \mathrm{~s}$, with a final extension at $72^{\circ} \mathrm{C}$ for $7 \mathrm{~min}$. The PCR product was sequenced, and the gene sequence was submitted to GenBank. The ORT isolates were designated by ORT/ species/location/time.

\section{Isolation and characterisation of H9N2 AIV}

Tissue samples, including lungs, pancreas and brain, were obtained aseptically from H9N2-positive broilers (detected by PCR). Approximately $100 \mathrm{mg}$ of minced tissue was suspended in sterile physiological saline. Gentamycin $(200 \mu \mathrm{g} / \mathrm{ml})$ was added to the suspension. The undiluted supernatant $(0.2 \mathrm{ml})$ was inoculated into 10 day-old specific-pathogen-free (SPF) chicken embryos. The eggs were candled daily, and the embryos that died within $24 \mathrm{~h}$ post inoculation (PI) were discarded. The allantoic fluid was collected, and virus was detected using a haemagglutination assay (HA). If no embryo death occurred, additional three blind passages were performed before designating any samples as negative. The antigenic characteristics of the virus subtype were determined by standard haemagglutination inhibition (HI), and the allantoic fluid containing virus was harvested and stored at $-80^{\circ} \mathrm{C}$ until use [15].

The viral RNA was extracted from the allantoic fluid using the QIAamp viral RNA mini kit (Qiagen, Germany) in accordance with the manufacturer's instruction. Reverse-transcription (RT) PCR was performed using specific primers [16]. The forward primer was 5'-CTY CAC ACA GAR CAC AAT GRR ATG-3', and the reverse primer was 5'-GTC ACA CTT GTT GTT GTR TC-3'. The RT-PCR was performed in a $50 \mu \mathrm{l}$ reaction mixture containing $10 \mu \mathrm{l}$ of $5 \times$ reaction buffer, $1 \mu \mathrm{l}$ of mixed dNTPs, $1 \mu \mathrm{l}$ of AMV enzyme, $2 \mu \mathrm{l}$ of each primer, $4 \mu \mathrm{l}$ of the RNA template, $2.5 \mu \mathrm{l}$ of DTT, and $27.5 \mu \mathrm{l}$ of distilled water. The PCR procedure was $94^{\circ} \mathrm{C}$ for $2 \mathrm{~min}, 30$ cycles of $94^{\circ} \mathrm{C}$ for $1 \mathrm{~min}, 53^{\circ} \mathrm{C}$ for $1 \mathrm{~min}, 68^{\circ} \mathrm{C}$ for $1 \mathrm{~min}$, and finally $68^{\circ} \mathrm{C}$ for $10 \mathrm{~min}$. The PCR products 
were subjected to electrophoresis in a $1 \%(\mathrm{w} / \mathrm{v})$ agarose gel and sequenced. The gene sequence was submitted to GenBank. The H9N2 virus isolate was designated by H9N2/species/location/time.

\section{Determination of the $\mathrm{LD}_{50}$ of ORT/chicken/Shandong/ 2011 and the ELD ${ }_{50}$ of H9N2/chicken/Shandong/2011}

After single colony purification in $5 \%$ sheep blood agar, the positive colonies were grown in bouillon medium for $48 \mathrm{~h}$ at $37^{\circ} \mathrm{C}$, and the number of colony formation units (CFU) in the culture was calculated post the inoculation.

Sixty 20-day-old healthy broilers were randomly assigned to six groups with 10 chickens per group and maintained in negative pressure isolators. The chickens were infected intraperitoneally with different dilutions of ORT/chicken/ Shandong/2011 in $0.5 \mathrm{ml}$, including $10^{0}, 10^{-1}, 10^{-2}, 10^{-3}$ and $10^{-4} \mathrm{cfu}$. Broilers inoculated intraperitoneally with sterile physiological saline served as a control group. Each group was observed daily for 14 days, and the $\mathrm{LD}_{50}$ was determined using the Reed-Muench method [17].

In another experiment, fifty 10-day-old SPF chicken embryos were randomly assigned to five groups with 10 eggs per group. Different dilutions of H9N2/chicken/ Shandong/2011 (0.2 ml) were injected into the allantoic space of the embryos. The eggs were incubated in a humidified atmosphere $(55 \%)$ at $37^{\circ} \mathrm{C}$. The allantoic fluid was harvested $120 \mathrm{hPI}$, and the $\mathrm{ELD}_{50}$ was determined using the Reed-Muench method [17].

\section{Experimental infection with ORT/chicken/Shandong/2011 and H9N2/chicken/Shandong/2011}

Sixty 21-day-old healthy broilers were randomly divided into six groups with 10 birds in each group. All of the birds were kept in negative pressure isolators. Group 1 was inoculated intraperitoneally with $10 \mathrm{LD}_{50}$ of ORT/ chicken/Shandong/2011 in $0.5 \mathrm{ml}$, and at the same time, $100 \mathrm{ELD}_{50}$ of H9N2/chicken/Shandong/2011 was administrated intranasally [12]. Group 2 received $10 \mathrm{LD}_{50}$ of ORT/chicken/Shandong/2011 intraperitoneally in $0.5 \mathrm{ml}$ and, three days later, received $100 \mathrm{ELD}_{50}$ of $\mathrm{H} 9 \mathrm{~N} 2 /$ chicken/Shandong/2011 intranasally. Group 3 was inoculated intranasally with $100 \mathrm{ELD}_{50}$ of $\mathrm{H} 9 \mathrm{~N} 2 /$ chicken/Shandong/2011 and, three days later, received $10 \mathrm{LD}_{50}$ of ORT/chicken/Shandong/2011 intraperitoneally. Group 4 birds were inoculated intraperitoneally with $10 \mathrm{LD}_{50}$ of ORT/chicken/Shandong/2011, and Group 5 was administered $100 \mathrm{ELD}_{50}$ of H9N2/chicken/ Shandong/2011 intranasally. Group 6 received an intraperitoneal injection of the sterile physiological saline as a negative control. Each group was observed daily, and all were sacrificed on day $14 \mathrm{PI}$. The broilers were euthanised by intraperitoneal injection of sodium pentobarbital. The gross lesions were inspected, and the main organs were collected for pathogen recovery.

\section{Results}

\section{Clinical survey of the ORT antibody}

A total of 291,000 birds, including 70,000 breeding broilers, 100,000 breeding layers, 95,000 broilers, 16,000 layers and 10,000 unaffected broilers were evaluated in this study. We totally collected 193 serum samples from the chickens for detection. Of the birds presenting with clinical signs, 127 of a total of $153(83 \%)$ sera were positive and of apparently healthy birds 6 of 40 (15\%) samples were seropositive (Table 1). With regards to age and seropositivity, the breeding species seroconverted at age 120 days to 280 days, the laying hens were around 120 days and the broilers were at day 32 to day 35 of age.

\section{Isolation and characterisation of ORT/chicken/ Shandong/2011}

ORT strain was successfully isolated from the lungs of diseased broilers by single colony purification. Subsequently, the isolate was classified using biochemical assays and a PCR assay. The strain was named ORT/ chicken/Shandong/2011. The colony formed by ORT/ chicken/Shandong/2011 was circular and small in size (1$3 \mathrm{~mm}$ in diameter), opaque to grey in colour and nonhaemolytic in sheep blood agar. The ORT isolate was found to be Gram negative and multi-form upon microscopic inspection (Figure 1). Furthermore, ORT/chicken/ Shandong/2011 showed the typical phenotypic traits of ORT (Table 2). The DNA extracted from the ORT/ chicken/Shandong/2011 colony produced the expected 784-bp PCR product from the $16 \mathrm{~S}$ rRNA. The sequence of the $16 \mathrm{~S}$ rRNA was submitted to GenBank (accession number JN415768). A sequence analysis of the $16 \mathrm{~S}$ rRNA segment showed that the sequence from this isolate was 98\%-100\% homologous with the ORT reference strains (GenBank \# HQ696786.1, U87100.1 and DQ860700.1).

\section{H9N2/chicken/Shandong/2011 identification}

The allantoic fluid of the inoculated embryos was positive by HA after the second passage of the virus in the SPF chicken embryos. The H9N2 virus was identified using a standard HI assay. Subsequently, the isolate was

\begin{tabular}{|c|c|c|c|c|c|}
\hline Species & Ages & $\begin{array}{l}\text { No. } \\
\text { stock }\end{array}$ & Samples & $\begin{array}{c}\text { No. } \\
\text { positive }\end{array}$ & $\begin{array}{c}\text { Positivity } \\
\text { (\%) }\end{array}$ \\
\hline Breeding broilers & $120-238$ & 70,000 & 46 & 30 & $65.2^{* *}$ \\
\hline Breeding layers & $170-280$ & 100,000 & 61 & 56 & $91.8^{* *}$ \\
\hline Broilers & $24-38$ & 95,000 & 31 & 26 & $83.8^{* *}$ \\
\hline Layers & 120 & 16,000 & 15 & 15 & $100.0^{* *}$ \\
\hline Total (infected) & & 281,000 & 153 & 127 & 83.0 \\
\hline Healthy broilers & $32-35$ & 10,000 & 40 & 6 & 15.0 \\
\hline
\end{tabular}

"*significantly different from the healthy broilers $(P<0.01)$. 


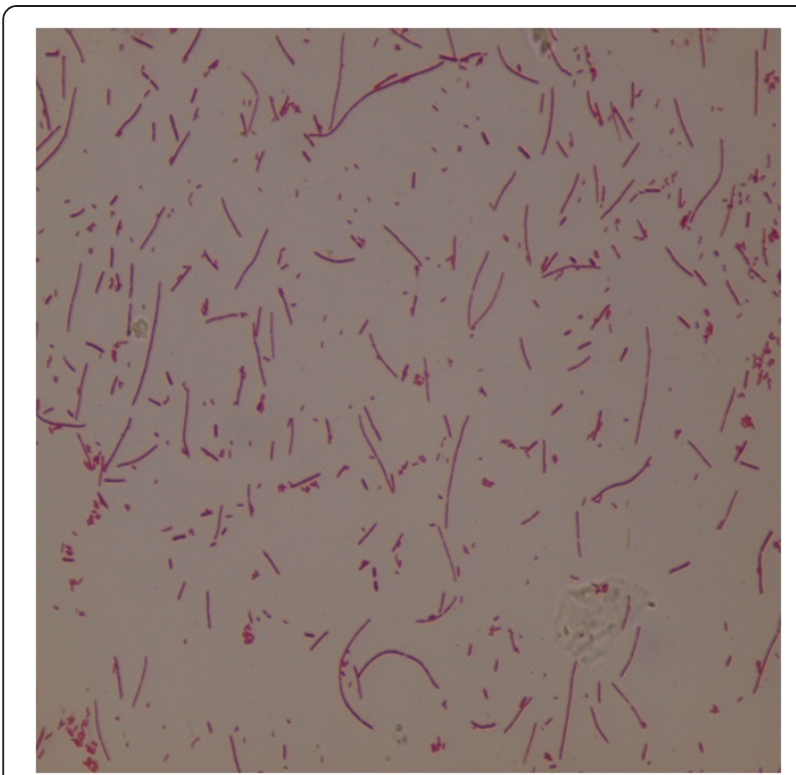

Figure $1 \mathrm{Gram}$ stain of a solid culture of ORT/chicken/ Shandong/2011 showing the pleomorphic shape of the isolate (Magnification $\times 1000$ ).

detected by RT-PCR, which yielded 468-bp amplicons. The gene sequence was submitted to GenBank (accession number JN566055). Corona virus-like particles were not detected in the allantoic fluid by RT-PCR. The sequence was 98\%-100\% homologous with H9N2 viruses, with accession numbers GU471873.1 and JF715009.1 in GenBank. In five severe cases, both ORT and H9N2 were isolated and identified in lungs from geographical

Table 2 The biochemical properties of the two ORT isolates

\begin{tabular}{lcc}
\hline Tests & $\begin{array}{c}\text { ORT/chicken/ } \\
\text { Shandong/2011 }\end{array}$ & $\begin{array}{c}\text { ORT/chicken/ } \\
\text { Inner Mongolia/2011 }\end{array}$ \\
\hline Triple sugar iron agar & - & - \\
Motility & - & - \\
Oxidase & + & - \\
Catalase & - & - \\
Indole & - & + \\
Urease & + & - \\
Lysine decarboxylase & + & - \\
Nitrate & - & - \\
Gelatinase & - & + \\
Sucrose & - & + \\
Glucose & + & + \\
Galactose & + & + \\
Lactose & + & + \\
Maltose & + & + \\
Fructose & & + \\
\hline
\end{tabular}

distribution. Moreover, the presence of ORT was often identified while positive $\mathrm{H} 9 \mathrm{~N} 2$ isolates alone were confirmed in the diseased poultry with lower mortality.

\section{$\mathrm{LD}_{50}$ of ORT/chicken/Shandong/2011 and ELD ${ }_{50}$ of H9N2/ chicken/Shandong/2011}

After growing in medium for $48 \mathrm{~h}$ at $37^{\circ} \mathrm{C}$, the concentration of ORT/chicken/Shandong/2011 was $2.49 \times 10^{9}$ $\mathrm{cfu} / \mathrm{ml}$. The highest mortality occurred in group 1 and group 2 post inoculated with the ORT/chicken/Shandong/2011 strain (Table 3), and the $\mathrm{LD}_{50}$ of ORT/chicken/ Shandong $/ 2011$ was determined to be $1.43 \times 10^{8} \mathrm{cfu} / \mathrm{ml}$ in broilers. The $\mathrm{ELD}_{50}$ of $\mathrm{H} 9 \mathrm{~N} 2 /$ chicken/Shandong/2011 was $10^{7.83} / \mathrm{ml}$ (Table 4 ).

\section{Experimental infection with ORT/chicken/Shandong/2011 and H9N2/chicken/Shandong/2011}

Some birds showed ruffled the feathers, inactivity and reduced appetite on day $2 \mathrm{PI}$ with ORT and H9N2 virus simultaneously, ORT followed by H9N2 virus or ORT alone. By day 3 PI, most of the chickens abruptly showed clinical signs of respiratory disease, including respiratory distress, and exhibited more severe anorexia and emaciation. The infected birds died between days 3 and 5 PI. The survival rate was $30 \%, 20 \%$ and $50 \%$ in the ORT $+\mathrm{H} 9 \mathrm{~N} 2$ virus group, ORT/H9N2 virus group, and ORT group, respectively. In contrast, birds inoculated with $\mathrm{H} 9 \mathrm{~N} 2$ virus followed by ORT or the H9N2 virus alone displayed typical pneumonia for 4 days, and no mortality occurred within 3 days PI. The infected chickens died quickly after inoculation with ORT alone, and the survival rate was up to $70 \%$, compared to $90 \%$ in the H9N2 group (Table 5). The infected birds displayed the typical lesions, such as fibrinous airsacculitis, pericarditis, peritonitis and scattered areas of haemorrhage in the lungs upon necropsy. No obvious gross lesions were observed in the liver and kidneys of the infected birds.

\section{Discussion}

In the current study, $83.0 \%$ of clinical blood samples from poultry farms were positive for ORT antibodies by ELISA. The ORT isolated from the infected lungs of a

Table 3 The determination of the $\mathrm{LD}_{50}$ of the ORT/ chicken/Shandong/2011 isolate

\begin{tabular}{lccccc}
\hline Group & No. & Dosage & Concentration & No. mortality & Mortality (\%) \\
\hline 1 & 10 & 0.5 & $2.49 \times 10^{9} \mathrm{cfu} / \mathrm{ml}$ & 10 & $10 / 10$ \\
2 & 10 & 0.5 & $2.49 \times 10^{8} \mathrm{cfu} / \mathrm{ml}$ & 6 & $6 / 10$ \\
3 & 10 & 0.5 & $2.49 \times 10^{7} \mathrm{cfu} / \mathrm{ml}$ & 1 & $1 / 10$ \\
4 & 10 & 0.5 & $2.49 \times 10^{6} \mathrm{cfu} / \mathrm{ml}$ & 0 & $0 / 10$ \\
5 & 10 & 0.5 & $2.49 \times 10^{5} \mathrm{cfu} / \mathrm{ml}$ & 0 & $0 / 10$ \\
6 & 10 & 0.5 & control & 0 & $0 / 10$ \\
\hline
\end{tabular}




\begin{tabular}{|c|c|c|c|c|c|}
\hline Group & No. & Volumes & Dilutions & No. Mortality & Mortality (\%) \\
\hline 1 & 10 & 0.2 & $10^{-6}$ & 10 & $10 / 10$ \\
\hline 2 & 10 & 0.2 & $10^{-7}$ & 10 & $10 / 10$ \\
\hline 3 & 10 & 0.2 & $10^{-8}$ & 4 & $4 / 10$ \\
\hline 4 & 10 & 0.2 & $10^{-9}$ & 0 & $0 / 10$ \\
\hline 5 & 10 & 0.2 & control & 0 & $0 / 10$ \\
\hline
\end{tabular}

32-day-old broiler grew on sheep blood agar, and the H9N2 virus was isolated from the same broiler and identified by HI and RT-PCR. Based on the sequence analysis, the Chinese ORT isolate is 98.0 to $100 \%$ homologous to other ORT isolates in GenBank. Broilers inoculated intraperitoneally with ORT/chicken/Shandong/2011 alone displayed pneumonia and typical airsacculitis, and coinfection of the broilers with ORT and H9N2 virus isolates induced higher mortality than infection with ORT or H9N2 virus alone. Therefore, these results satisfy Koch's postulates for confirming the role of a suspected bacterial pathogen in disease. The results of this study strongly suggest that co-infection with ORT and H9N2 virus is responsible for the current severe pneumonia with high mortality in broilers of China.

In our clinical setting, ORT was associated with 20-30 $\%$ and $10-20 \%$ mortality in broilers and layers, respectively. However, the birds infected with the ORT isolated in this study had a $50 \%$ mortality rate, and a co-infection with the H9N2 virus resulted in 70\% death. Our findings suggest that primary infection with ORT might play a major role in the development of severe pneumonia, and secondary infection with $\mathrm{H} 9 \mathrm{~N} 2$ further increases the mortality. These findings are different from previous reports in which no pneumonia or airsacculitis was induced by aerosol, intra-tracheal or intra-thoracic inoculation with ORT alone [18]. Only intravenous inoculation has been reported to induce clinical signs in SPF chickens, with at most $20 \%$ mortality [19], and no airsacculitis has been previously seen in the field. Given these conflicting results, it is uncertain if ORT should be regarded as a primary pathogen [1]. Additionally, it is generally acknowledged that ORT and Avian pneumovirusvirus (APV) infections synergistically aggravate respiratory symptoms in turkeys. An aerosol inoculation of ORT without a viral primer did not result in lesions [20,21]. Furthermore, viral agents could trigger higher mortality independent of ORT infection, such as NDV [1] and APV [21,22]. A recent report confirmed that IBV and E. coli infection exacerbated ORT pathogenesis in adult laying hens [23]. However, none of the above-mentioned viruses were identified in the present study. Interestingly, the birds infected with ORT alone developed an exudative pneumonia and extensive haemorrhage in the lungs and kidneys. This pattern of pathology is not consistent with previous reports. These histological results indicate that this newly isolated ORT is different from formerly reported ORT serotypes [20-22,24]. Because the serotype of the ORT isolated in this study is unclear, further investigation is needed to identify its specific serotype and characterise ORT pathogenesis based on serotype. After inoculation of broilers with ORT and H9N2 virus together, widespread haemorrhage and fibrosis in the respiratory tract were the most notable features of the infection, which led to occlusion of the air capillaries, respiratory distress and the increased mortality. These histopathological lesions are analogous to those described in birds late during the course of avian influenza H9N2 infection alone $[11,14]$. Notably, the severe pulmonary fibrosis was observed in the animals inoculated first with ORT followed by the H9N2 virus. The clinical signs and the respiratory lesions observed during necropsy of the birds infected with the H9N2+ORT combination and the H9N2

Table 5 Experimental infections with ORT/chicken/Shandong/2011 and H9N2/chicken/Shandong/2011

\begin{tabular}{lccccc}
\hline Groups & No. & No. survival & Survival rate (\%) & ORT recovery & H9N2 recovery \\
\hline 1 & 10 & 3 & 30.0 & 3 & 2 \\
2 & 10 & 2 & 20.0 & 7 & 2 \\
3 & 10 & 5 & 70.0 & 5 & 5 \\
4 & 10 & 9 & 50.0 & 9 & 9 \\
5 & 10 & 10 & 90.0 & 0 & 0 \\
\hline
\end{tabular}

Indications:

Group 1 chickens were inoculated intraperitoneally with 10 LD $_{50}$ of ORT/chicken/Shandong/2011 in 0.5 ml, and 100 ELD 50 of H9N2/chicken/Shandong/2011 was administrated intranasallyin $0.2 \mathrm{ml}$ at the same time.

Group 2 chickens were given $10 \mathrm{LD}_{50}$ of ORT/chicken/Shandong/2011intraperitoneally in $0.5 \mathrm{ml}$ and received 100 ELD 50 of H9N2/chicken/Shandong/ 2011 intranasallyin $0.2 \mathrm{ml}$ three days later.

Group 3 birds were inoculated intranasally with $100 \mathrm{ELD}_{50}$ of H9N2/chicken/Shandong/2011in $0.2 \mathrm{ml}$ and three days later received intraperitoneally with $10 \mathrm{LD}_{50}$ of ORT/chicken/Shandong/2011in $0.5 \mathrm{ml}$.

Group 4 birds were inoculated intraperitoneally with 10 LD $_{50}$ of ORT/chicken/Shandong/2011in $0.5 \mathrm{ml}$.

Group 5 chickens were given $100 \mathrm{ELD}_{50}$ of H9N2/chicken/Shandong/2011intranasally in $0.2 \mathrm{ml}$.

Group 6 birds received the sterile physiological saline intraperitoneally as a negative controlin $0.5 \mathrm{ml}$. 
group confirm that ORT, not a viral agent, triggers the overt respiratory symptoms.

Our findings are also different from previous reports in which ORT could be involved in infections with $E$. coli O2:K1 [22], Bordetella avium [25], and Chlamydophila psittaci [26] as well as a combination of E. coli and APV [22]. In our pilot study (unpublished data), E. coli and Chlamydophila psittaci were occasionally identified in the latter phase of the ORT infection. However, coinfection of ORT and E. coli or Chlamydophila psittaci could not reproduce the typical pathology of the pneumonia and airsacculitis, such as clots of fibrin in the air sacs and haemorrhage in lungs. In the co-infection, ORT may dominate the primary infection, followed by secondary bacterial infections. ORT was isolated and identified in birds with clinical signs immediately after hatching in the previous reports [24]. In current study, ORT/chicken/Liaoning/2010 was isolated from the egg yolks of the breeder's eggs, suggesting the possibility of vertical transmission from parents to offspring.

\section{Conclusion}

Our data show that ORT infections have been occurring frequently in China. The current experimental study confirmed that ORT infection alone could induce high mortality. Moreover, ORT infection could produce a higher level of mortality and economic loss if H9N2 AIV was also present. Although ORT and the H9N2 virus have been isolated and identified separately in previous reports, this is the first report of co-infection of broilers with ORT and H9N2 AIV, and this co-infection might be probably associated with the outbreak of broiler airsacculitis in China, which caused an extensive economic loss. Therefore, further investigation of the resistance and pathogenesis of ORT is urgently needed.

\section{Abbreviations}

ORT: Ornithobacterium rhinotracheale; AIV: Avian influenza virus; HA: Haemagglutination assay; HI: Haemagglutination inhibition; IBV: Infectious bronchitis virus; NDV: Newcastle disease virus; ELISA: Enzymelinked immunosorbent assay; PCR: Polymerase chain reaction; CFU: Colony formation units; PI: Post inoculation; SPF: Specific pathogen free.

\section{Acknowledgements}

This work was supported by the University's Research Project for college students (URP). The authors appreciated the assistance from Professor Xiaoling Chen (Beijing Academy of Agriculture and Forestry Sciences, China) for her kind donation of two ORT reference strains.

\section{Author details}

'Key Lab of Animal Epidemiology and Zoonosis, Ministry of Agriculture, College of Veterinary Medicine, China Agricultural University, Beijing 100193, China. ${ }^{2}$ Beijing Veterinary Biological Manufactory, Beijing 102600, China. ${ }^{3}$ College of Veterinary Medicine, China Agricultural University, Yuanmingyuan Xilu, Haidian District, Beijing 100193, P.R. China.

\section{Authors' contributions}

QP contributed to the study design, evaluated the data, and drafted and wrote the manuscript. AL isolated and characterised the ORT. FZ isolated and characterised the AIV H9N2. YL collected the samples and helped contact the chicken farmers. CO performed the statistical analyses. NH helped with the ELISA.CH contributed to the study design, obtained the funding, and evaluated the microarray. All authors have read and approved the final manuscript.

Received: 8 November 2011 Accepted: 2 July 2012 Published: 2 July 2012

\section{References}

1. Van Empel P, Hafez H: Ornithobacterium rhinotracheale: a review. Avian Pathol 1999, 28:217-227.

2. Canal CW, Leao JA, Rocha SLS, Macagnan M, Lima-Rosa CAV, Oliveira SD, Back A: Isolation and characterization of Ornithobacterium rhinotracheale from chickens in Brazil. Research in Vet Sci 2005, 78:225-230.

3. Charlton BR, Channing-Santiago SE, Bickford AA, Cardona CJ, Chin RP, Cooper GL, Droual R, Jeffrey JS, Meteyer CU, Shivaprasad HL, Walker RL: Preliminary characterization of a pleomorphic gram-negative rod associated with avian respiratory disease. J Vet Diagn Invest 1993, 5:47-51.

4. Devriese LA, Hommez J, Vandamme P, Kersters K, Haesebrouck F: In vitro antibiotic sensitivity of Ornithobacterium rhinotracheale strains from poultry and wild birds. Vet Rec 1995, 137:435-436.

5. Erganis O, Ates M, Hadimli HH, Corlu M: Isolation of Ornithobacterium rhinotracheale from chickens and turkeys. Turk J Vet Anim Sci 2002, 26:543-547.

6. Hafez $\mathrm{H}$ : Control approaches of respiratory disease of poultry. In 1st International Veterinary Poultry Congress, Iran Branch of the WVPA and Veterinary Council, February 19-20, 2008, Tehran, Iran. 2008:8-47.

7. Mohammad H, Vahid K, Neda F, Iradj A: Molecular characterization of Ornithobacterium rhinotracheale isolated from broiler chicken flocks in Iran. Turk J Vet Anim Sci 2010, 34:373-378.

8. Van Empel P, van den Bosch H, Loeffen P, Storm P: Identification and serotyping of Ornithobacterium rhinotracheal. J Clin Microbiol 1997, 35:418-421.

9. Vandamme $P$, Segers $P$, Vancanneyt $M$, van Hove $K$, Mutters $R$, Hommez J, Dewhirst F, Paster B, Kersters K, Falsen E, Devrieze L, Bisgaard M, Hinz K-H, Mannheim W: Ornithobacterium rhinotracheale gen. nov. sp. nov., isolated from the avian respiratory tract. Int J Syst Bacteriol 1994, 44:24-37.

10. Butt KM, Chen GJ, Chen H, Zhang LJ, Leung YH, Xu KM, Lim W, Webster RG, Yuen KY, Peiris JS, Guan Y: Human infection with an avian H9N2 influenza A virus in Hong Kang in 2003. J Clin Microbiol 2005, 43:5760-5767.

11. Guo YJ, Krauss S, Senne DA, Mo IP, Lo KS, Xiong XP, Norwood M, Shortridge KF, Webster RG, Guan Y: Characterization of the pathogenicity of members of the newly established H9N2 influenza virus lineage in Asia. J Virol 2000, 267:279-288.

12. Haghighat-Jahromi M, Asasi K, Nili H, Dadras H, Shooshtari AH: Coinfection of avian influenza virus (H9N2 subtype) with infectious bronchitis live vaccine. Arch Virol 2008, 153:651-655.

13. Swayne DE, Senne DA, Beard CW: Isolation and identification of avian pathogens. 4th edition. Pennsylvania, USA: American Association of Avian Pathology; 1998

14. Deng G, Bi J, Kong F, Li X, Qiang Xu, Dong J, Zhang M, Zhao L, Luan Z, LV N, Qiao J: Acute respiratory distress syndrome induced by H9N2 virus. Arch Virol 2010, 155:187-195.

15. The World Organisation for Animal Health (OIE): Avian Influenza, Manual of Diagnostic Tests and Vaccines for Terrestrial Animals, vol. 1. In Office International des Epizooties. 2008:467-481.

16. Zhang $T$, Zhang $H$, Zheng J, Zhang H, Chen L, Wang W: Isolation and characterization of avian influenza virus H9N2 subtype in Guangxi province of China. China Poultry 2011, 33:50-51.

17. Reed $\amalg$, Muench $H$ : A simple method of estimation of $50 \%$ end points. Am J Hyg 1938, 27:493-497.

18. Van Empel P, Vrijenhoek M, Goovaerts D, van den Bosch H: Immunohistochemical and serological investigation of experimental Ornithobacterium rhinotracheale infection in chickens. Avian Pathol 1999, 28:187-193.

19. Goovaerts D, Vrijenhoek M, van Empel P: Immunohistochemical and bacteriological investigation of the pathogenesis of Ornithobacterium rhinotracheale infection in South Africa in chickens with osteitis and encephalitis syndrome. In Proceedings of the 16th meeting of the European Society of Veterinary Pathology, Lillehammer; 1998:81. 
20. Allymehr M: Seroprevalence of Ornithobacterium rhinotracheale infection in broiler and broiler breeder chickens in west Azerbaijan Province, Iran. $J$ Vet Med A 2006, 53:40-42.

21. Van Empel P, van den Bosch H, Goovaerts D, Storm P: Experimental infection in turkeys and chickens with Ornithobacterium rhinotracheale. Avian Dis 1996, 40:858-864.

22. Marien M, Decostere A, Duchateau L, Chiers K, Froyman R, Nauwynck H: Efficacy of enrofloxacin, florfenicol and amoxicillin against Ornithobacterium rhinotracheale and Escherichia coli O2:K1 dual infection in turkeys following APV priming. Vet Microbiol 2007, 121:94-104.

23. Thachil AJ, Velayudhan BT, Shaw DP, Halvorson DA, Nagaraja KV: Pathogenesis of Ornithobacterium rhinotracheale in egg-laying hens with coexisting infectious bronchitis virus and Escherichia coli infections. J Appl Poult Res 2009, 18:780-788.

24. Tanyi J, Bistyk A, Kaszanyitzky E, Vetesi F, Dobos-Kovacs M: Isolation of Ornithobacterium rhinotracheale from chickens, hens and turkeys showing respiratory symptoms. Magyar Allatorvosok Lapja 1995/1996, 50:328-330.

25. El-Sukhon Saeb N, Asad Musa, Majed Al-Attar: Studies on the bacteria etiology of airsacculitis of broilers in northern and Middle Jordan with special reference to Escherichia coli, Ornithobacterium rhinotracheale, and Bordetella avium. Avian Dis 2002, 46:605-612.

26. Van Loock M, Geens T, De Smit L, Nauwynck H, Van Empel P, Naylor C, Hafez HM, Goddeeris BM, Vanrompay D: Key role of Chlamydophila psittaci on Belgian turkey farms in association with other respiratory pathogens. Vet Microbiol 2005, 107:91-101.

doi:10.1186/1746-6148-8-104

Cite this article as: Pan et al:: Co-infection of broilers with

Ornithobacterium rhinotracheale and H9N2 avian influenza virus. BMC

Veterinary Research 2012 8:104.

\section{Submit your next manuscript to BioMed Central and take full advantage of:}

- Convenient online submission

- Thorough peer review

- No space constraints or color figure charges

- Immediate publication on acceptance

- Inclusion in PubMed, CAS, Scopus and Google Scholar

- Research which is freely available for redistribution 